\title{
Histological analysis of the tongue, esophagus and crop of Southern Carcará
}

\section{(Polyborus plancus)}

\author{
Análise histológica da língua, esófago e papo do Carcará do Sul (Polyborus plancus) \\ Análisis histológico de lengua, esófago y buche de Carcará do Sul (Polyborus plancus)
}

Received: 01/28/2021 | Reviewed: 02/02/2021 | Accept: 02/05/2021 | Published: 02/11/2021

\author{
Vanessa Sobue Franzo \\ ORCID: https://orcid.org/0000-0001-9957-8942 \\ Federal University of Mato Grosso, Brazil \\ E-mail:vsfranzo@hotmail.com \\ Leiny Paula de Oliveira \\ ORCID: https://orcid.org/0000-0002-4728-0674 \\ Federal University of Goiás, Brazil \\ E-mail: ly.paula@hotmail.com \\ Ana Carolina Pôssas Viana \\ ORCID: https://orcid.org/0000-0003-2862-4926 \\ Vittalab Veterinary Laboratory, Country \\ E-mail: carol_skallpe@ @otmail.com \\ Adriano Tony Ramos \\ ORCID: https://orcid.org/0000-0001-8744-5309 \\ Federal University of Santa Catarina, Brazil \\ E-mail: adriano.ramos@ufsc.br \\ Jéssica Fernanda Bertolino \\ ORCID: https://orcid.org/0000-0002-9766-3235 \\ Federal University of Goiás, Brazil \\ E-mail: jessicafbertolino@hotmail.com \\ Barbara Ataide Adorno \\ ORCID: https://orcid.org/0000-0002-7051-3552 \\ Federal University of Jataí, Brazil \\ E-mail: b.a.adorno@gmail.com \\ Diego Pereira de Araújo \\ ORCID: https://orcid.org/0000-0003-0986-6890 \\ Federal University of Goiás, Brazil \\ E-mail: diegoaraujomv@outlook.com \\ Lizandra Amoroso \\ ORCID: https://orcid.org/0000-0001-9848-7803 \\ State University Paulista Júlio de Mesquita Filho, Brazil \\ E-mail: lizandra.amoroso@gmail.com. \\ Valcinir Aloisio Scalla Vulcani \\ ORCID: https://orcid.org/0000-0001-5968-330X \\ Federal University of Jataí, Brazil \\ E-mail: aloisiosv@ hotmail.com
}

\begin{abstract}
The Southern Caracara is a bird of prey, of the family Falconidae, inhabits all the Brazilian territory, they are omnivorous birds adapted for hunting. The digestive system of the predators presents differences in their morphology due to their eating habits. Knowing the importance of the gastrointestinal system, this study aims to carry out a histological study of the tongue, esophagus and the crop of Polyborus plancus. For this purpose, eight avian of both sexes, with different body weights and ages were used, they were euthanized and the organs were collected, fixed, dehydrated and stained with hematoxylin-eosin. It was noted that the tongue has stratified squamous epithelium with mucous glands and with different degrees of keratinization. The esophagus and crop have four well developed muscle layers and mucous glands. Additionally, in the crop there is presence of an adventitious layer that consists of loose connective tissue. We conclude that the tongue, the esophagus and the crop of the Southern Caracara have similar histological organization of several birds like the Pekin Ducks, ostriches, domestic chicken and partridges.
\end{abstract}

Keywords: Birds; Digestion; Morphology; Digestive system.

\section{Resumo}

O carcará é uma ave de rapina, da família Falconidae, habita todo o território brasileiro, são aves onívoras adaptadas para a caça. O sistema digestório dos rapinantes apresenta diferenças na sua morfologia devido aos seus hábitos alimentares. Sabendo-se a importância do sistema gastrointestinal, esse estudo tem como objetivo realizar estudo histológico da língua, do esôfago e do papo do Polyborus plancus. Para isto, foram utilizados oito exemplares de 
ambos os sexos, com diferentes pesos corpóreos e faixas etárias. Esses animais foram eutanasiados e os órgãos coletados, fixados, desidratados e corados com hematoxilina-eosina. Notou-se que, a língua possui epitélio pavimentoso estratificado, com glândulas mucosas e com diferentes graus de queratinização. O esôfago e o papo possuem quatro camadas musculares bastante desenvolvidas e glândulas mucosas. Há no papo a presença de camada adventícia constituída por tecido conjuntivo frouxo. Conclui-se que a língua, o esôfago e o papo do carcará possuem organização histológica semelhante a diversas aves como o marreco de Pequim, avestruzes, galinhas domésticas e perdizes.

Palavras-chave: Aves, Digestão; Morfologia; Sistema digestório.

\section{Resumen}

El carcará es un ave rapaz, de la familia Falconidae, habita en todo el territorio brasileño, son aves omnívoras adaptadas para la caza. El sistema digestivo de los depredadores presenta diferencias en su morfología debido a sus hábitos alimenticios. Conociendo la importancia del sistema gastrointestinal, este estudio tiene como objetivo realizar un estudio histológico del lenguaje, el esófago y el cultivo de Polyborus plancus. Para ello se utilizaron ocho ejemplares de ambos sexos, con diferentes pesos corporales y grupos de edad. Estos animales se sacrificaron y los órganos se recogieron, fijaron, deshidrataron y tiñeron con hematoxilina-eosina. Se observó que la lengua presenta epitelio escamoso estratificado, con glándulas mucosas y con diferentes grados de queratinización. El esófago y el buche tienen cuatro capas de músculos y glándulas mucosas muy desarrolladas. En el cultivo hay una capa de adventicia formada por tejido conectivo laxo. Se concluye que la lengua, el esófago y el caracol del carcará tienen una organización histológica similar a la de varias aves como el pato de Pekín, avestruces, pollos domésticos y perdices.

Palabras clave: Aves; Digestión; Morfologia; Sistema digestivo.

\section{Introduction}

Carnivorous birds that have adaptations to hunt are named birds of prey and feature predatory ability. These birds have a curved and sharp beak, their claws are strong, and their hearing and eyesight are well developed, these adaptations provide better abilities to capture their preys (Ferguson-Less; Christie, 2001; Menq, 2011).

The Southern Caracara is a rural bird of prey from the order Falconiformes, family Falconidae, that inhabits all Brazilian territory, and it is commonly observed in urban areas (Sick, 2001; Franzo Et Al., 2009; Iucn, 2013). It weighs about one kilogram and has approximately 120 to $130 \mathrm{~cm}$ of wingspan (Mckinney, 2009).

They are considered omnivorous, and their feed is wide, composed mainly of fruits, cadaveric remains, small mammals, other birds and annelids (SICK, 2001). Their digestion is mainly enzymatic, as observed in carnivorous (Dukes, 1996).

In general terms, the digestive system is constituted by various structures responsible for the digestion and absorption of nutrients necessary to the normal organic functioning (Dukes, 1996). The organs that are part of this system are responsible by the prehension, mastication, deglutition, digestion and absorption of the food, and by expelling the residues, eliminated as feces (Macari et al., 1994).

The gastrointestinal system of birds is compound by beak, tongue, oropharynx, esophagus, ingluvies or crop, glandular stomach or proventriculus, mechanical stomach or gizzard, small intestine, Meckel's diverticulum, large intestine (compounded by two cecum and rectum), and cloaca. These organs enable prehension, deglutition, physiochemical transformations of the feed, nutrients absorption and excretion (Boaro, 2009; Rocha Et Al, 2014).

In birds of prey, the gastrointestinal system has differences when compared to the other vertebrates and even to other birds. They are adaptions in their morphology that are related to their feeding habit. Birds as the Southern Caracara utilize enzymatic digestion as a result of the food ingested, consequently they have a large stomach and relatively short intestines. In contrast, birds that ingest fibrous food have developed cecum, that harbors microorganisms that participates in the fermentation and digestion of cellulose. Birds that ingest food of easy digestion have a simple and short digestive tract (Godoy, 2013).

The tongue is located in the oral cavity, which in the chicken is located in the caudal portion of the oropharynx and is fixated in the skeleton by a cartilage (Dyce et al., 2010). With its triangular and narrow shape, the tongue is composed by 
striated musculature and lined by stratified squamous epithelium, the tongue epithelium is continuous with the oral cavity mucosa (Boaro, 2009). It is sustained by a delicate hyoid apparatus and is not prone. It creates the movement of the food bolus in the interior of the oropharynx and its propulsion to the interior of the esophagus during the deglutition (Dukes, 1996).

The esophagus of birds is a muscular tube, located between the oropharynx and the glandular area of the stomach, its walls have a large distention when compared to the esophagus of mammals (Dyce et al., 2010). The esophagus mucosa has glands that synthetize mucus, which is important to the protection of the mucosa against abrasion and lubricate the food (Penz E Magro, 1998; Bacha \& Bacha, 2003).

The crop, or ingluvies, is basically a storage organ. The entry of the food bolus is controlled, mainly, by the esophagus muscle tone over this area, through stretch receptors located on the crop wall (Noy \& Sklan, 1995; Denbow, 2000).

The digestive system organs have, in their wall composition, various layers with distinct functions (Bacha \& Bacha, 2003). The mucosa, which is near the lumen of the digestive tract, is responsible for direct contact with the food, toxins and microorganisms, it has a stratified squamous epithelium and typical lamina propria (Bacha \& Bacha, 2003; Eurell \& Frapper, 2012). The submucosa has connective tissue as support and glands to secrete digestive substances. The muscular layer is responsible by the contractions and the serous layer coats the organs externally being free of microorganisms (Benez, 2004).

Thus, this paper has as objective to analyze the microscopic morphology of the tongue, esophagus and crop of the Southern Caracara and to compare with other avian species already researched, in order to provide biological data to other researches in the field of morphophysiological science.

\section{Methodology}

The experiment was conducted in the Faculdade de Ciências Agrárias e Veterinárias, campus of Jaboticabal, Unesp, and in the Escola de Medicina Veterinária e Zootecnia (EMVZ), campus of Araguaína, UFT, where it was conducted a study for histological evaluation of some organs of the digestive system such as the tongue, the esophagus and the crop of the Southern Caracara.Eight samples of the Southern Caracara (Polyborus plancus) with distinct body weight and age groups were utilized, being four males and four females. They were provided by the Setor de Silvestres do Departamento de Patologia Animal da UNESP, campus Jaboticabal, whose IBAMA license was given by the Proc. IBAMA number 02027.000933/05-47. The procedures were conducted after being approved by the Comitê de Ética e Bem-Estar animal (CEBEA), under the register 007590-05.

Prior to euthanasia, the animals received general anesthesia with propofol $(15 \mathrm{mg} / \mathrm{kg})$ administered intravenously, certifying unconsciousness through the absence of eyelid, corneal and podal reflexes. Subsequently, the animals were euthanized by administration of potassium chloride ( $0.5 \mathrm{ml} / \mathrm{animal})$ intravenously (Cfmv, 2012; Rocha 2015).

For the histological analysis samples of two centimeters were collected from the tongue, the cranial esophagus, the crop and the caudal esophagus, which were cut open longitudinally, washed in phosphate buffer solution and fixed in Bouin's solution for 24 hours. Posteriorly, the samples were washed by successive immersions in $70 \%$ alcohol to remove the fixative and dehydrate the samples in a series of increasing concentrations of alcohols (Tolosa et al., 2003).

After dehydration, the samples were cut into fragments of $0,5 \mathrm{~cm}$ of length, diaphonized in xylene, impregnated and paraffin-embedded. The paraffin-embedded material was processed and the sections destined for histology were stained with hematoxylin-eosin.

The sections were analyzed using an optical microscope and the images registered by an image

pickup apparatus. In sequence, the images were analyzed by a computer using the software Pro Plus 4.1 (Media Cybernetics, Bethesda, USA). 


\section{Results and Discussion}

It was observed that the tongue of the Polyborus plancus is formed by stratified squamous epithelium with areas presenting different degrees of keratinization. The posterior area, near the pharynx presented the higher thickness of the keratin layer. Below the epithelium has loose connective tissue in which it was visualized a large amount of mucous glands that open caudally to the keratinized epithelial plaque (Figure 1). The epithelium observed is similar to the epitheliums of domestic chickens observed by Dyce et al. (2010), of partridges observed by Rossi et al. (2005), and of Roadside hawk observed by Firmino et al. (2014). The central area of the tongue there is a supporting tissue (entoglossal bone) that was already described in other birds (Bacha \& Bacha, 2003; Gartner, 2003).

Figure 1. Tongue of Polyborus plancus. The presence of stratified squamous epithelium (E) keratinized (Q) is observed. Below the epithelium has connective tissue (arrow) and large amount of mucous glands (G). Transverse section. H.E. 100X.

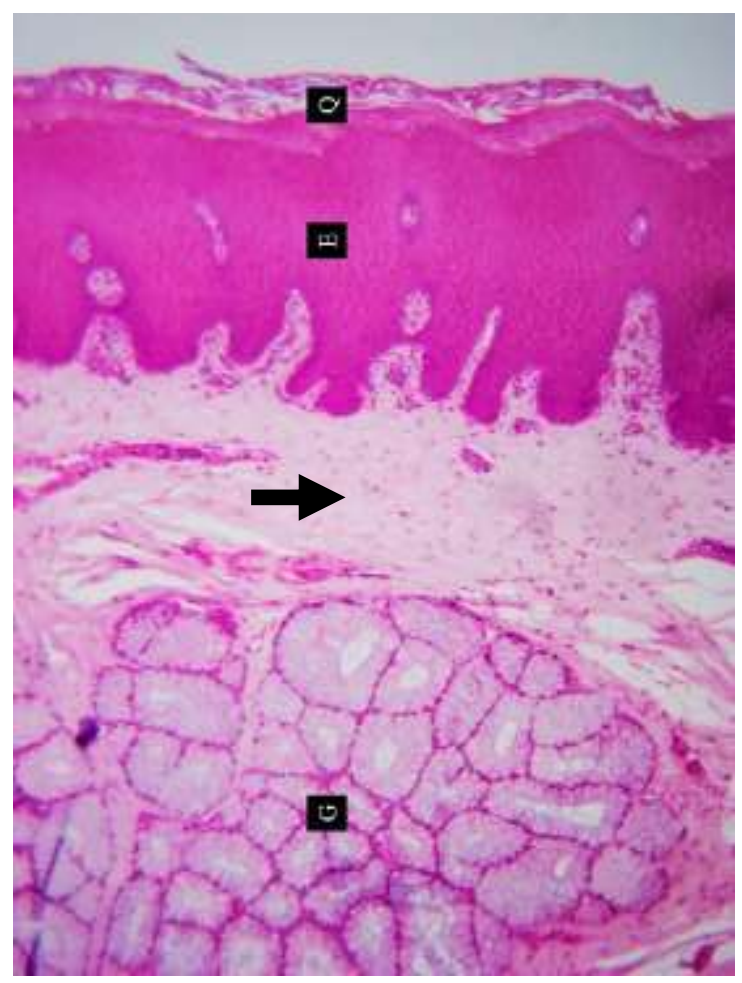

Source: Author

It was noted that the esophagus and the crop of the Southern Caracara have four layers: mucosa, submucosa, muscular, and serous in the esophagus and adventitia in the crop. Furthermore, in the crop of this bird stratified squamous epithelium and the presence of the adventitia formed by connective tissue were observed. The esophagus is lined with stratified squamous non-keratinized epithelium, with simple mucous glands in the connective tissue lamina propria. The muscularis externa consists of a thick inner layer of circular and a thin outer layer of longitudinal smooth muscle (Figure 2). 
Figure 2. Esophagus of Polyborus plancus. A - Stratified squamous non-keratinizing epithelium (*), connective tissue (black arrow), simple mucous gland (arrowhead), glandular duct through the epithelium (white arrow).100X. B - Muscularis externa composed by a circular layer $\left(^{*}\right)$ and a longitudinal layer (arrowhead) of smooth muscle. 100X. C - Detail of stratified squamous non-keratinizing epithelium (white line). 400X. D - Detail of connective tissue (white line). 400X. Transverse section. H.E.

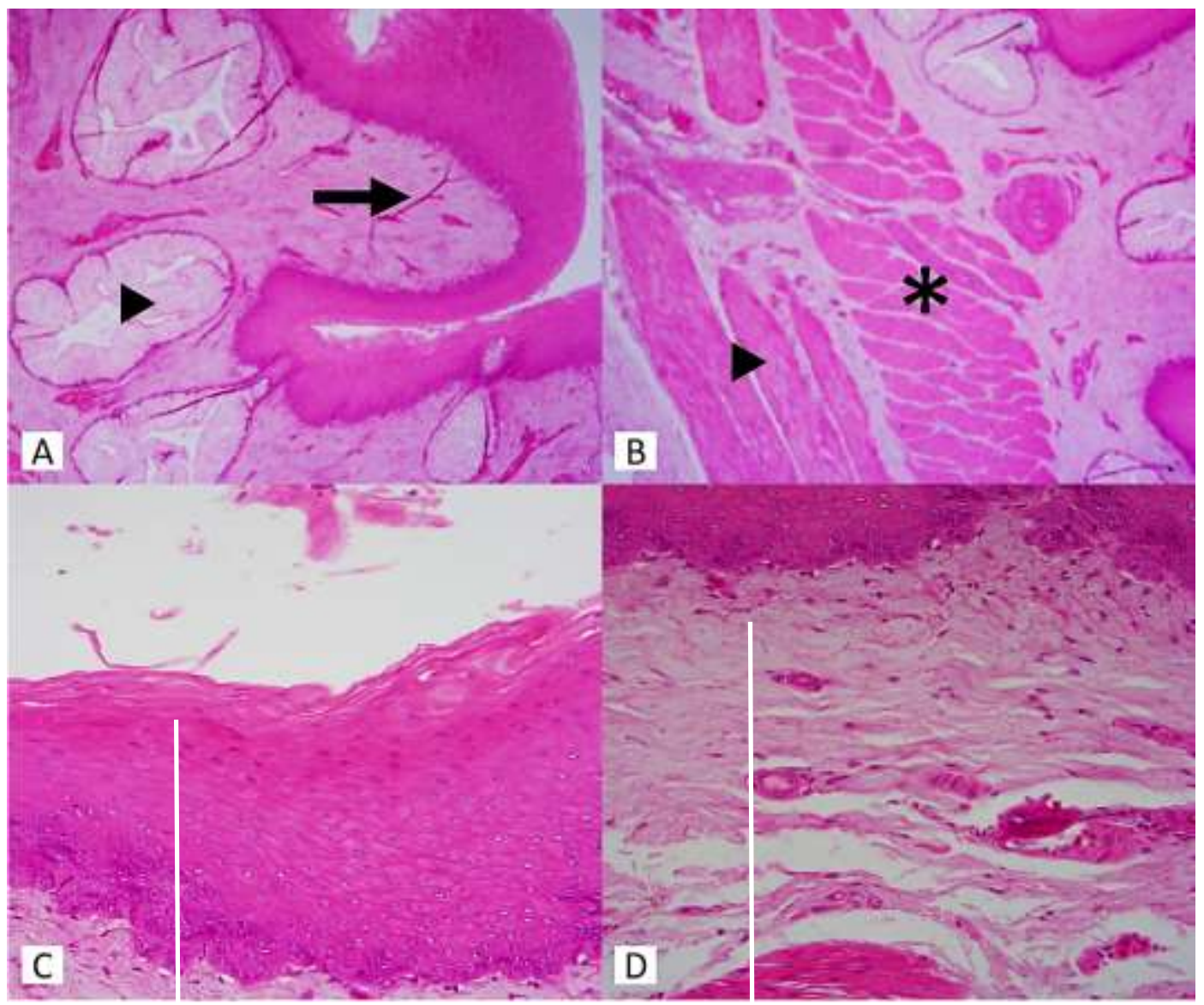

Soucers: Authors.

In the research by Silva et al. (2006) it was observed in Pekin Ducks (Anas platyrhynchos domesticus) the same epithelium as the Southern Caracara. In studies with ostriches (Struthio camelus) by Monteiro Et al. (2009) showed that the esophagus epithelium is similar with the epithelium of the Pekin Ducks and Southern Caracara. In addition, the submucosa layer has dense or loose connective tissue, with glands and blood vessels, similar with what was observed in the Roadside hawk (Firmino et al., 2014) and in other birds (Bacha \& Bacha, 2003; Dyce et al., 2010). The esophagus mucosa has mucous glands, important to protect the mucosa layer (Bacha \& Bacha, 2003; Eurell \& Frapper, 2012).

The muscular layers are responsible by the motility of the food bolus with movements named peristalsis (Dukes, 1996) from the oropharynx to the proventriculus (Dyce Et al., 2010). Moreover, it is noticeable the adventitia layer formed by loose connective tissue and mesothelium as described by Gartner (2003) and Eurell and Frapper (2012).

It was noticed and increased muscle thickness in the esophagus of the Polyborus plancus in the medium and distal areas. Additionally, it was observed the presence of non-keratinized squamous stratified epithelium with mucous glands whose cytoplasm was clear, with little tinctorial affinity, the flattened nuclei in the basal portion and a quite apparent muscular layer.

In the histological analysis, the cranial esophagus presented similar structures from the caudal esophagus in which the mucosa epithelium is squamous stratified arranged longitudinally. Furthermore, it was noted that the mucosa is twisted in 
longitudinal folds allowing the organ dilatation and the accommodation of the food bolus (Dukes, 1996; Frandson et al., 2003).

The Southern Caracara, which is a bird of prey, presented inherent and consistent characteristics with the microscopic morphology of omnivorous birds, according to the description in other birds. This knowledge becomes important, due to its contribution with information to understand bird adaptation in their habitat, as well as to correlate with eating habits. Moreover, the morphology provides the basis to clinical approaches and surgery of domestic and wild species, whose demand is increasing in the country.

\section{Conclusion}

With the present work, it was concluded that, the Southern Caracara from the specie Polyborus plancus, have a histological organization of the tongue, the esophagus and the crop similar to the described in partridges (Rhynchotus rufescens), Roadside hawk (Rupornis magnirostris), Pekin duck (Anas platyrhynchos domesticus), ostriches (Struthio camelus) and domestic chickens (Struthio camelus) e galinhas domésticas (Gallus gallus domesticus).

\section{References}

Bacha, W. J., \& Bacha, L. M. (2003). Atlas colorido de histologia veterinária. (2nd ed), 457: Roca. 457p.

Benez, S. M. (2004). Aves: criação, clínica, teoria e prática. (4th ed).: Tecmedd.

Boaro, M. (2009). Morfofisiologia do trato intestinal. In: Conferência facta de ciência e tecnologia avícolas. 261-274: Facta

CFMV, Conselho Federal de Medicina Veterinária. Guia Brasileiro de Boas Práticas em Eutanásia em Animais - Conceitos e Procedimentos Recomendados Brasília. (2012).

Denbow, D. M. (2000). Gastrointestinal anatomy and physiology. (15th ed). In: Whittow, G. C. Sturkie's avian physiology, 298-341: Academic Press.

Dukes, G. E (1996). Digestão nas aves. In: Swenson, M. J., \& Reece, W. O. Dukes fisiologia dos animais domésticos. (11th ed), 390-397: Guanabara-Koogan.

Dyce, K. M. (2010). Anatomia das aves. In: Dyce, K. M. et al. Tratado de anatomia veterinária. (4th ed): Elsevier.

EurelL, J. A., \& Frapper, B. L. (2012). Histologia Veterinária de Dellmann. (6th ed): Manole.

Ferguson-Less, J., \& Christies, D. A. (2001). Raptors of the world: Houghton Mifflin Company.

Firmino, M. O., Siqueira, R. A. S., Luna, A. C. L., Cavalcante, T. A., \& Guerra, R. R. (201). Caracterização biométrica externa, avaliação corpórea e caracterização histológica do trato gastrintestinal de gaviões-carijó (Rupornis magnirostris) apreendidos pelo CETAS/IBAMA na Paraíba. Biotemas, 27 (1), $101-108$.

Frandson, R. D., Lee Wilke, W., \& Dee Fails. (2003). Anatomia e fisiologia dos animais de fazenda. (6th ed): Guanabara Koogan.

Franzo, V. S., Pereira Júnior, R. A., Oliveira, J. T., Vulcani, V. A. S., Baealdi Artoni, S. M., Werther, K., \& Filadelpho, A. L. (2009). Estudo Biométrico do Esôfago do carcará (Polyborus plancus, Miller, 1777). Revista Científica Eletrônica de Medicina Veterinária, 18 (1), 1-9.

Gartner, L. P. (2003). Tratado de histologia. (2nd ed): Guanabara Koogan, 472.

Godoy, M. F. (2013). El sistema digestivo en diferentes espécies de aves. http://uniciencia.ambientalex.info/infoCT/Sisdigdifespavear.pdf .

List, Iucn Red. (2013). The IUCN Red List of Threatened Species. Version 2013.1: www.iucnredlist.org.

Macari, M., Furlan, R. L., \& Gonzales, E. (1994). Fisiologia aviária aplicada a frangos de corte: FUNEP, 296.

Mckinney, T. (2009). Anthropogenic Change and Primate Predation Risk: Crested Caracaras (Caracara plancus) Attempt Predation on Mantled Howler Monkeys (Alouatta palliata). Neotropical Primates, 16 (1), 24-27.

Menq, W. (2011). Portal aves de rapina Brasil - Gavião carijó. 2011. http://www.avesderapinabrasil.com/.

Monteiro, C. M. R., Souza, N. T. M., Carvalho, R. G., \& Souza, W. M. (2009). Análise histológica do trato gastrintestinal de avestruzes jovens (Struthio camelus Linnaeus, 1758). Biotemas, 22 (3), 149-155

Noy, Y., \& Sklan, D. (1995). Digestion and absorption in the young chick. Poultry Science, 74 (2), 366-373.

Penz, A. M., \& Magro, N. (1998). Granulometria de rações: Aspectos fisiológicos. Simpósio sobre granulometria de ingredientes e rações para suínos e aves, 1-9. http://www.cnpsa.embrapa.br/sgc/sgc_publicacoes/publicacao_e0s20p2z.pdf 
Research, Society and Development, v. 10, n. 2, e21410212439, 2021

(CC BY 4.0) | ISSN 2525-3409 | DOI: http://dx.doi.org/10.33448/rsd-v10i2.12439

Rocha, P. et al. (2014). Anatomia comparada do sistema digestório da família Accipitridae: Buteo albicaudatus (Vieillot, 1816), Parabuteo unicinctus (Temminck, 1824) e Rupornis magnirostris (Gmelin, 1788). Livro de resumos do VII Encontro sobre Animais Selvagens (ENANSE), II Simpósio sobre Medicina e Conservação da Fauna do Cerrado.

Rocha, R W., \& EscobaR, A. (2015). Anestesia em aves. Revista Investigação: Medicina Veterinária, 2 (14), 1-9.

Rossi, R. R., Artoni, S. M. B., Oliveira, D., Cruz, C., Franzo, V. S., \& Sagula, A. (2005). Morfologia do bico e da língua de perdizes Rhynchotus rufescens. Ciência Rural, 35 (5), 1098-1102.

Sick, H. (2001). Ornitologia brasileira (4th ed), 862: Nova Fronteira.

Silva, D. A., Nakaghi, L. S. O., Makino, L. C., Paullio, A. C., \& Nishizawa, M. (2006). Histologia do sistema digestório de marrecos de Pequim (Anas platyrhyncos) jovens e adultos. $14^{\circ}$ Simpósio internacional de iniciação científica da USP.

Tolosa, E. M. C. et al. (2003). Manual de técnicas para histologia normal e patológica. 241: Manole. 